Корнівська В. О., д.е.н.

ДУ «Інститут економіки та прогнозування

Національної академії наук України»

м. Київ, Украӥна

DOI: https://doi.org/10.30525/978-9934-26-107-7-3

\title{
СОЦІАЛЬНИЙ КОНТЕКСТ ПРИМУСОВОЇ РЕСТРУКТУРИЗАЦІЇ БОРГІВ ДОМОГОСПОДАРСТВ
}

Зростання боргів домогосподарств на фоні коливань наявного доходу - це довгострокова тенденція, яка трансформує економічне та соціоінституційне середовище, створюючи системні ризики, не тільки у країнах, що розвиваються, але й у розвинутих країнах. Глобальні тенденції зростання боргів домогосподарств розвиваються сьогодні і в українській системі фінансово-інституційних координат. При цьому фінансова поведінка українських ринкових суб'єктів має певні особливості, що стосуються боргової дисципліни. Так, на фоні досить помірної кредитної активності високою лишається частка непрацюючих кредитів. Істотний вплив на розвиток таких тенденцій мають зростаючі проблеми бідності та збільшення комунальних боргів, що мають першість по відношенню до боргів перед банківськими установами. Це зумовлює перманентні ризики зростання частки кредитів, що не обслуговуються, в умовах зростання кредитної активності. Зростання попиту на кредити, зокрема на іпотеку, що зараз відмічається українськими банківськими установами, черевате розвитком іпотечного буму 3 подальшим кризовим вирівнюванням, тому має бути під пильним державним контролем.

В умовах економічної дестабілізації нормативне врегулювання реструктуризації боргів домогосподарств стає чи не єдиним шляхом вивільнення населення із боргової пастки. Прикладом цього $є$ нещодавно прийняті в Україні законодавчі нововведення як відповідь на наслідки локдаунів. Дані нововведення, будучи 
важливим кроком не тільки для забезпечення короткострокової усталеності українських домогосподарств, але й кроком до посилення соціальної відповідальності банківських установ, водночас мають амбівалентний характер.

23 квітня 2021 року вступили у силу Закони України [1], що покликані захистити домогосподарства, які отримали споживчі кредити у іноземній валюті, але не змогли своєчасно здійснювати платежі за цими кредитами. Серед експертів вони викликали негативний резонанс, серед недоліків зазначалися, зокрема, такі: безпідставне розповсюдження умов обов'язкової (примусової) реструктуризації на всі споживчі кредити в іноземній валюті, за якими грошові зобов'язання повністю не погашено, зокрема й ті, що обслуговуються належним чином; негативні для державного бюджету наслідки (зменшення фінансового результату до оподаткування кредитора та несплата до бюджету податку на прибуток кредитора у розмірі 18\% від суми погашення і від курсової різниці); недієвість пропонованого механізму реструктуризації кредитів, який передбачає лише подання заяви про проведення реструктуризації, але подальші дії сторін незрозумілі. Вважалося, що реалізація пропонованих законодавчих нововведень може призвести до банкопаду, під час останнього 3 них 3 Держбюджету було витрачено понад 250 мільярдів гривень [1].

У цьому зв'язку Верховна Рада уточнила, що ці нововведення спрямовані на відновлення платоспроможності позичальників, які отримали споживчі кредити в іноземній валюті, але не змогли своєчасно здійснювати платежі за цими кредитами; вони передбачають запровадження загального механізму реструктуризації усіх споживчих валютних кредитів фізичних осіб шляхом конвертації їх у гривню i визначають порядок та умови проведення такої реструктуризації на підставі заяви боржника.

Очевидно, що, викликаючи істотні заперечення у представників банківської спільноти, які розглядають таку реструктуризацію як примусову, пропоновані зміни у законодавстві виступають на боці позичальників. 
Для того, щоб обгрунтувати прийнятність законодавчих нововведень слід звернутися до світового досвіду врегулювання реструктуризації, особливо звертаючи увагу на можливість іiі примусової реалізації.

Спочатку розглянемо економічну сутність реструктуризації. Реструктуризація боргу - це процес, який використовується компаніями, приватними особами і навіть країнами в цілях уникнення ризику несплати своїх наявних боргів. Коли боржник знаходиться у скрутному фінансовому становищі, реструктуризація боргу є менш витратною альтернативою банкрутству, і це може спрацювати на користь як позичальника, так і позикодавця. Зазвичай, процес реструктуризації боргу спрямований на зменшення відсоткових ставок за позиками або пролонгацію термінів їх повернення. Стандартна практика реструктуризації передбачає ринкові механізми врегулювання, згоду кредитора на проведення цієї процедури за наявності відповідних, встановлених банком схем. Якщо у цьому процесі не вдається добитися взаємовигідних умов як для боржника, так i для кредитора, то західна практика реструктуризації приватних боргів та боргів компаній налічує багато інституцій, що організують цей процес, у тому числі, агенцій з реструктуризації, компаній з питань споживчих кредитів, медіаторів.

Водночас глобальна фінансово-економічна криза 2007-2009 pp. та наступна за нею рецесія показали, що в умовах крайньої дестабілізації для вирішення боргових проблем приватних осіб та господарюючих суб'єктів послуг посередників стає замало, необхідним $є$ державне втручання. Оскільки, наприклад, зростання боргів домогосподарств не тільки дестабілізує економіку, воно призводить до соціальних зворушень. Тому добре розроблене та ефективно впроваджене державне втручання в умовах фінансово-економічної біфуркації завжди $є$ більш прийнятним, ніж вирішення проблем реструктуризації боргів лише ринковими силами та через судову систему [2]. Держава може прийняти інституційну участь, створюючи нормативні умови для реструктуризації боргів банківськими установами, 
може розробляти державні програми i приймати фінансову участь у їх реалізації, водночас бувають ситуації, коли у держав немає важелів фіскального впливу, у таких умовах реалізуються примусові реструктуризації.

У червні 2000 року у рамках боротьби із зростанням обсягів простроченого корпоративного боргу уряд Уругваю впровадив програму, на основі якої банки були змушені пролонгувати терміни погашення позик (за умови поступового збільшення щомісячних виплат). Подібні кроки мали суперечливі результати, 3 одного боку, вони були позитивними з точки зору взаємодії у площині держава-ринковий суб'єкт, адже примусова реструктуризація завжди демонструє, що держава на боці позичальників, тому політичні дивіденди незаперечні. Також у короткостроковому періоді відбулося тимчасове послаблення боргового тиску, що надало можливості сконцентруватися на операційній діяльності боржника та знайти вихід із боргової залежності. Водночас примусова реструктуризація порушує ринкові механізми, адже вона зменшує переговорну силу банків, при цьому зростає ризик судового оскарження та потенціал погіршення кредитної культури [3].

У цьому контексті цікавий також досвід Угорщини. У 2011 р. заборгованість угорських домогосподарств в іноземній валюті була однією з найвищих у Східній Свропі (при цьому загальний борг домогосподарств досягнув 40\% ВВП і був зосереджений приблизно у 800000 домогосподарств (або 20\% від загальної кількості)). Різке знецінення угорського форинту після початку світової фінансової кризи призвело до того, що зростаючі обсяги обслуговування боргу підривали приватне споживання. Це змусило владу допомогти домашнім господарствам. Після ряду невдалих спроб надати допомогу (таких, як тимчасовий мораторій на виплату боргів, ініціатива щодо добровільної реструктуризації), уряд запровадив обов'язкову програму реструктуризації боргу у вересні 2011 року без попередніх консультацій із зацікавленими сторонами. Протягом фіксованого періоду (приблизно п'ять місяців) банки були змушені дозволяти 
клієнтам виплачувати свої іпотечні кредити за пільговим обмінним курсом, приблизно на $30 \%$ нижче ринкового. Практично 15\% всіх іпотечних кредитів було таким чином реструктуровано. Усі витрати, а згодом і збитки були покладені лише на банки [3]. Безумовно, угорські банки стали значно обережнішими щодо кредитування населення, i починаючи 3 2015 року коливальні тенденції операційної активності 3 домогосподарствами призвели до того, що показник глибини кредитування за п'ять років практично не змінився: у 2015 році 21,2\% ВВП у 2020 році - 21,0\% ВВП.

Примусова реструктуризація - загалом амбівалентна система заходів: виключно необхідна 3 точки зору соціального клімату, економічної усталеності домогосподарств, політичної стабільності, але складна та витратна з позиції банківських установ, крім того, високим є моральний ризик, створюваний шляхом надання боржникам можливості не повертати кошти на початкових умовах позики. Отже, програми примусової реструктуризації мають бути спрямованими на зменшення вимог щодо обслуговування боргу певних позичальників, які зазнали фінансової дестабілізації через збільшення планових виплат за кредитами внаслідок несприятливих шокових ставок або обмінного курсу, або на вирішення проблеми накопичення значної кількості непрацюючих позик.

Головною метою програм реструктуризації має бути перетворення проблемних позик на позики, що виконуються. У цьому не тільки їх важливий економічний зміст, але й соціальний, що полягає у створенні позитивного фінансово-інституційного клімату високої фінансової культури взаємодії у площині домогосподарства - держава - банківські установи.

\section{Література:}

1. Юдіна Т. Законопроекти про реструктуризацію банківських кредитів несуть загрозу економічної кризи - експерти. URL: https://www.unn.com.ua/ uk/news/1924839-zakonoproekti-pro-restrukturizatsiyu-bankivskikh-kreditiv-nesut-zagrozu-ekonomichnoyi-krizi-eksperti. 
2. Laeven Luc, Laryea Thomas. Principles of Household Debt Restructuring. URL: https://www.imf.org/external/pubs/ft/spn/2009/spn0915.pdf

3. World economic outlook: Growth resuming, dangers remain. International Monetary Fund. April 2012. 